Brit. J. industr. Med., 1950, 7, 27-36.

\title{
EFFECT OF ALUMINIUM ON THE SILICOSIS-PRODUCING ACTION OF INHALED QUARTZ
}

\author{
BY \\ E. J. KING, B. M. WRIGHT,* S. C. RAY, and C. V. HARRISON \\ From the Postgraduate Medical School of London
}

(RECEIVED FOR PUBLICATION SEPTEMBER 2, 1949)

The claim of Denny and others $(1937 ; 1939)$ to have prevented silicosis in quartz-dusted animals by the simultaneous administration of aluminium was not substantiated in the experiments of Belt and King (1943) and of King and others (1945), using the intratracheal injection technique of Kettle and Hilton (1932). But it was pointed out by King (1947), in similar experiments, that the aluminium might disappear from the lungs of animals which had received a single dose of mixed quartz and aluminium by the intratracheal route, leaving the quartz behind to exert its fibrogenic action after all the aluminium had been dissolved. It may be, therefore, that aluminium can exert its preventive or retardative action on silicosis production only if it is constantly renewed in small amounts in the lungs. The only type of experiment where this can be easily accomplished is one in which both the quartz and the aluminium are administered by daily inhalation. During the last ten years several attempts have been made in this laboratory to produce silicosis in rats, guinea-pigs, and rabbits by the tumble-mill dusting technique of Denny and others, and to prevent silicosis by dusting similar animals simultaneously, or alternately, with quartz dust from a rubber-lined mill and aluminium from a mill of aluminium containing shot and slugs of the metal. These experiments have been unsuccessful. In the present experiment a new kind of cabinet and a new method of producing dust clouds have been used (Wright, 1948); and success has finally been obtained in preventing, or at any rate retarding, the production of silicosis in the lungs of a majority of rats given aluminium and quartz to breathe, as compared with marked and rapidly developing silicosis in the lungs of control rats breathing quartz dust without the admixed aluminium.

\section{Apparatus}

The cabinet and the mechanism for producing the dust cloud are shown in Figs. 1 and 2. Dry, filtered air from an electric blower was fed into each of the two cabinets at a rate of 10 litres per minute, and carried with it finely dispersed quartz dust, or quartz plus 2 per cent. powdered aluminium, to produce in each a dust cloud uniform both in composition and concentration, and averaging ( \pm 20 per cent.) 30,000 particles per ml. Air was drawn through filters from each cabinet by a compressed air ejector and carried to the exterior through a tube leading out of a window of the room. Each cabinet was furnished with a safety hatch, which was designed to open automatically should there be any failure in the supply of air entering through the dustfeed mechanism. The doors and walls of the cabinets contained glass windows, through which the animals could be observed.

The dusty atmospheres were sampled by means of the thermal precipitator of Green and Watson (1935), which was placed inside the cabinets on top of the animal cage. Thermal precipitator counts were made daily during the initial stages of the experiment, but it was found that a sample filtration apparatus would suffice for the daily routine check of the concentrations of the dust clouds. This consisted of a small piece of black filter paper (Whatman No. 29), mounted in a metal clip fitting into an opening in the door of the cabinet, and a 10-litre aspirator through which water was drained at about one litre an hour, so as to draw air through the filter paper, causing a white stain $(1 \mathrm{~cm}$. diameter) of deposited dust to appear on the black paper. Frequent comparison of these filter paper samples with microscopic counts made from those taken with the thermal precipitator demonstrated that they were surprisingly accurate as well as being very easy to execute. With a little practice, and by comparison with an album of known filter-paper samples, the operator was able to assign values to dust counts in the range of 15,000 to 50,000 particles per ml., which agreed, with an error of not more than 3,000 particles, with those yielded by the thermal precipitator.

\section{Quartz and Aluminium}

The powdered quartz was kindly furnished by $\mathrm{Mr}$. J. N. Wilson of Messrs. Colin Stewart Ltd. It had

* Now at the Medical Research Council Pneumoconiosis Research Unit, Cardiff. 
TABLE 1

SIZE DISTRIBUTION OF POWDERED QUARTZ AND ALUMINIUM

\begin{tabular}{|c|c|c|c|c|c|c|}
\hline & Size & & $\begin{array}{l}\text { Perce } \\
\text { of } q \\
\text { part }\end{array}$ & $\begin{array}{l}\text { age } \\
\text { irtz } \\
\text { les }\end{array}$ & $\begin{array}{l}\text { Perce } \\
\text { of alur } \\
\text { part }\end{array}$ & $\begin{array}{l}\text { tage } \\
\text { inium } \\
\text { les }\end{array}$ \\
\hline & & & $\underset{\text { number }}{\text { By }}$ & $\begin{array}{c}\text { By } \\
\text { mass }\end{array}$ & $\begin{array}{c}\text { By } \\
\text { number }\end{array}$ & $\begin{array}{c}\text { By } \\
\text { mass }\end{array}$ \\
\hline $\begin{array}{c}\text { Under } \\
\text { ", } \\
\text { ", } \\
\text { ", } \\
\text { ", } \\
\text { ", }\end{array}$ & $\begin{array}{l}0.25 \\
0.5 \\
1 \cdot 0 \\
1 \cdot 5 \\
2 \\
3 \\
4 \\
5 \\
6 \cdot 25 \\
7 \cdot 5\end{array}$ & $\begin{array}{l}\ldots \\
\ldots \\
\ldots \\
\ldots \\
\ldots \\
\ldots \\
\ldots \\
\ldots \\
\ldots\end{array}$ & $\begin{array}{r}8 \\
29 \\
67 \\
84 \\
92 \\
98 \\
99 \\
99 \\
100\end{array}$ & $\begin{array}{c}0 \cdot 04 \\
0 \cdot 8 \\
12 \\
20 \\
31 \\
54 \\
62 \\
70 \\
70 \\
100\end{array}$ & $\begin{array}{r}\overline{46} \\
72 \\
83 \\
89 \\
98 \\
100 \\
- \\
-\end{array}$ & $\begin{array}{r}\overline{2} \\
11 \\
26 \\
40 \\
78 \\
100 \\
- \\
-\end{array}$ \\
\hline
\end{tabular}

previously been shown to produce massive fibrosis in the lungs of rats when administered by the intratracheal route by King and others (1948). Its size distribution is given in Table 1.

The powdered aluminium was obtained from $\mathrm{Mr}$. R. J. Ennis of the McIntyre Porcupine Mine, Ontario, to whom we are indebted. This material was identical with that used by Denny and others in their animal experiments, and by Crombie and others (1944) in the prophylaxis and therapy of human silicosis.

An intimate mixture of 2 per cent. (by weight) of the aluminium with 98 per cent. of the quartz was made by shaking the two dusts together. The silica solubilities of the quartz dust and of the mixture of quartz plus aluminium are given in Table 2 ; the dissolution of the quartz powder in the Ringer's fluid is depressed almost to zero by the presence of the aluminium. The quartz failed to stain with aurine when treated with the dye in ammoniacal buffer; whereas the aluminium-treated quartz stained markedly, yielding a red powder from which the dye could not be washed and due, presumably, to a coating of alumina having been formed on the surface of each particle of quartz, the alumina taking the aurine dye strongly (compare Denny and others, 1937).

\section{Animals}

Piebald (black and white, or hooded) rats were used. They were from the Medical Research Council strain employed in previous experiments in this laboratory. Two groups of seventeen male rats, of about $200 \mathrm{~g}$. and nearly the same age, were selected to give as nearly as possible the same distribution of litter mates. The seventeen animals were accommodated easily in an 18 in. $\times 18$ in. cage which fitted into the cabinet. In the off-dusting periods they were transferred from these cages to larger ones for exercise and feeding.

\section{Dusting and Duration of the Experiment}

During the initial period of the experiment the rats were dusted for a few hours only each day; but it was later found possible greatly to increase the dusting
TABLE 2

SILICA SOLUBILITIES OF QUARTZ AND QUARTZ-PLUSALUMINIUM

$(0.2$ g. of dust shaken with $10 \mathrm{ml}$. buffered $(p \mathrm{H} \mathrm{7.4})$ Ringer solution for 48 hours at $37^{\circ} \mathrm{C}$.)

\begin{tabular}{|c|c|c|c|}
\hline \multirow{2}{*}{\multicolumn{3}{|c|}{$\begin{array}{l}\text { Quartz (commercial C.S.) ... } \ldots \\
\text { Quartz }+2 \% \text { aluminium powder... }\end{array}$}} & $\begin{array}{l}\text { Dissolved silica } \\
\left(\mathrm{mg} . \mathrm{SiO}_{2} / 100 \mathrm{ml} .\right)\end{array}$ \\
\hline & & & $\begin{array}{l}3 \cdot 6 \\
0 \cdot 1\end{array}$ \\
\hline$+1 \%$ & , & ," & $0 \cdot 1$ \\
\hline$+0.5 \%$ & ,, & ... & $0 \cdot 1$ \\
\hline$+0.2 \%$ & ,, & $\cdots$ & $0 \cdot 1$ \\
\hline$+0.1 \%$ & , & ... & \\
\hline$+0.05 \%$ & , & ... & \\
\hline , & , & ", & \\
\hline
\end{tabular}

periods, and to maintain them in the cabinets overnight. The rats were transferred to the cleaned cabinet cages at 3 p.m. each day; they were placed in the cabinets with food and water and the dusting was begun. The desired concentration of -dust was quickly reached, and was maintained overnight until 9 a.m. the next day. This exposure to 30,000 particles per $\mathrm{ml}$. for eighteen hours a day, five days a week (except for holidays and periods when the apparatus required adjustment or repair), was maintained for over a year (see Table 3). At first we were apprehensive that the rats would not tolerate such large quantities of dust for so long each day. But there were no quick deaths in either cabinet, and it was necessary to kill animals at intervals in order to follow the progress of the lung changes produced by the inhaled dust. All animals in the quartz-plus-aluminium group had been killed or were dead by the four-hundredth day, and the four remaining rats in the quartz group were then killed and the experiment finished (Table 3). Some of the rats that died, particularly in the quartz group, were lost through cannibalism, their bodies, including the lungs, being eaten by their mates during the night. Because of this, the lungs from only twelve animals were recovered from the quartz group, and fourteen from the quartz-plus-aluminium group.

\section{Pathological Technique}

The removal of lungs, insufflation with formol saline, fixation, embedding, and sectioning were carried out as in former experiments we have reported (Belt and King, 1945). Routine sections across the middle of both lungs and including the hilar lymph glands were cut in all cases, and stained with hæmatoxylin and eosin, with Gordon and Sweet's (1936) silver impregnation for reticulin, and occasionally with van Giesen's or Mason's stain. Two unstained serial sections were always subjected to micro-incineration (one with $\mathrm{HCl}$ treatment) to reveal the presence and disposition of mineral matter in the lungs and in the lesions.

\section{Chemical Analyses}

The portions of fixed lung tissue which were not used for histology were dried to constant weight at $105^{\circ} \mathrm{C}$., finely powdered, and submitted to analysis for silica and 


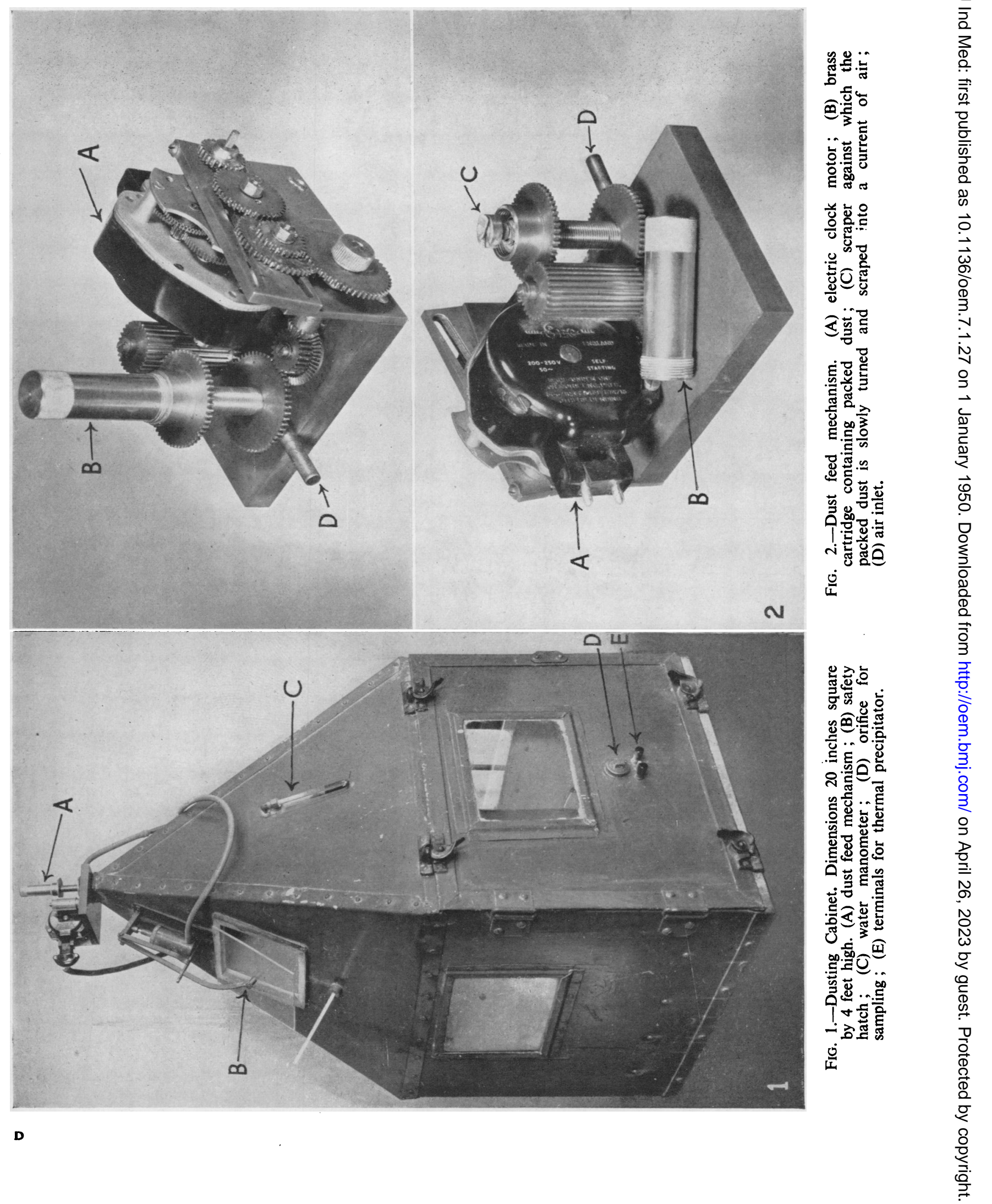




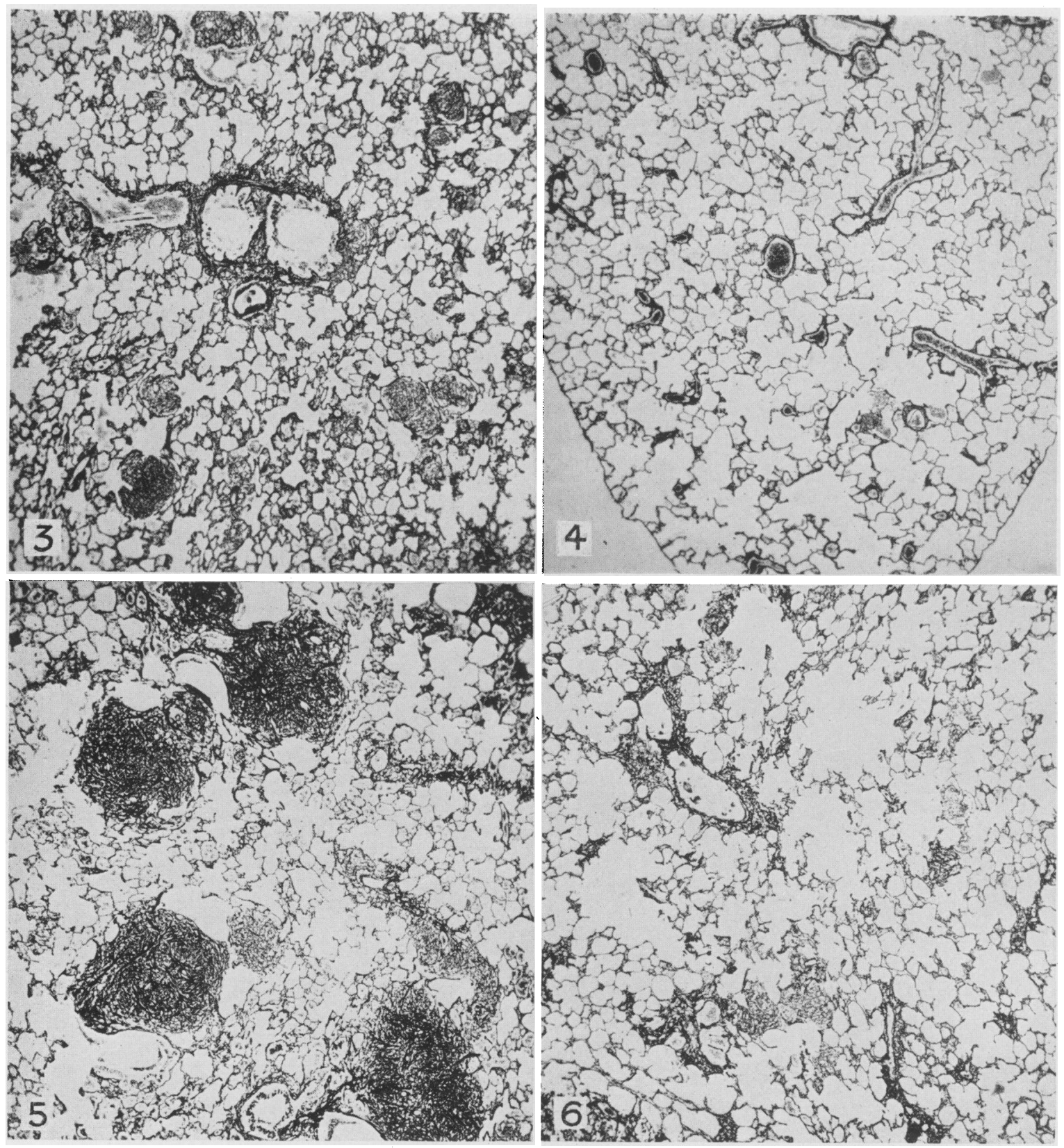

FIG. 3.-Pure quartz. Rat 5 : 222 days' survival. Early nodules of raticulinosis. (Silver impregnation, $x$ 28.)

FIG. 5.-Pure quartz. Rat 6: 306 days' survival. Several large nodules of collagenous fibrosis and also early nodules of looser reticulinosis. (Silver impregnation, $x$ 28.)
Fig. 4.-Quartz-plus-aluminium. Rat 4: 201 days' survival. Solitary focus of reticulinosis (the largest found). Compare with Fig. 1. (Silver impregnation, $x$ 28.)

Fig. 6.-Quartz-plus-aluminium. Rat 6: 306 days' survival. Small foci of loose reticulinosis. Compare with Fig. 3. (Silver impregnation, $x$ 28.) 

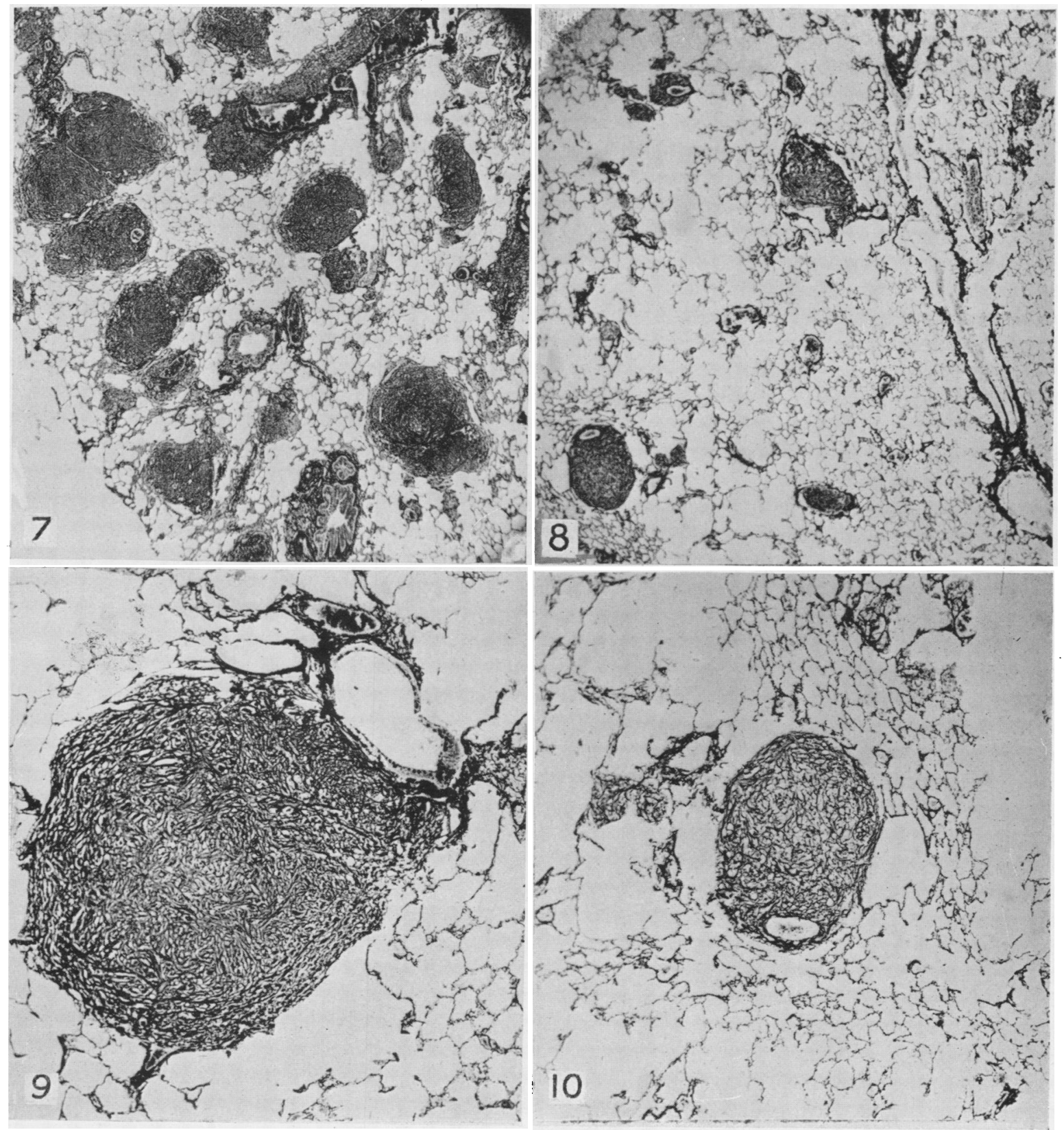

FIG. 7.-Pure quartz. Rat 14: 408 days' survival. Crowded nodules of dense collagen with a few smaller nodules of reticulinosis. (Silver impregnation, $x$ 25.)

FIG. 9.-Pure quartz. Same rat as Fig. 7. High-power view of a nodule to show its size and dense collagenous structure. (Silver impregnation, x 60.)

FIG. 8.-Quartz-plus-aluminium. Rat 16: 397 days' survival. Rounded nodules of reticulinosis. Compare with fig. 5. (Silver impregnation, $x$ 25.)

FIG. 10.-Quartz-plus-aluminium. Same rat as Fig. 8. High-power view of a nodule to show its smaller size and looser reticulin structure. (Silver impregnation, $x$ 60.) 
FIG. 11.-Same field as Fig. 7. Incinerated section showing silica ash. ( $x$ 25.)

Fig. 13.-Quartz-plus-aluminium. Lobule of same lung as Fig. 8. showing many nodules of reticulinosis (more dense than in Fig. 8, but not collagenous).
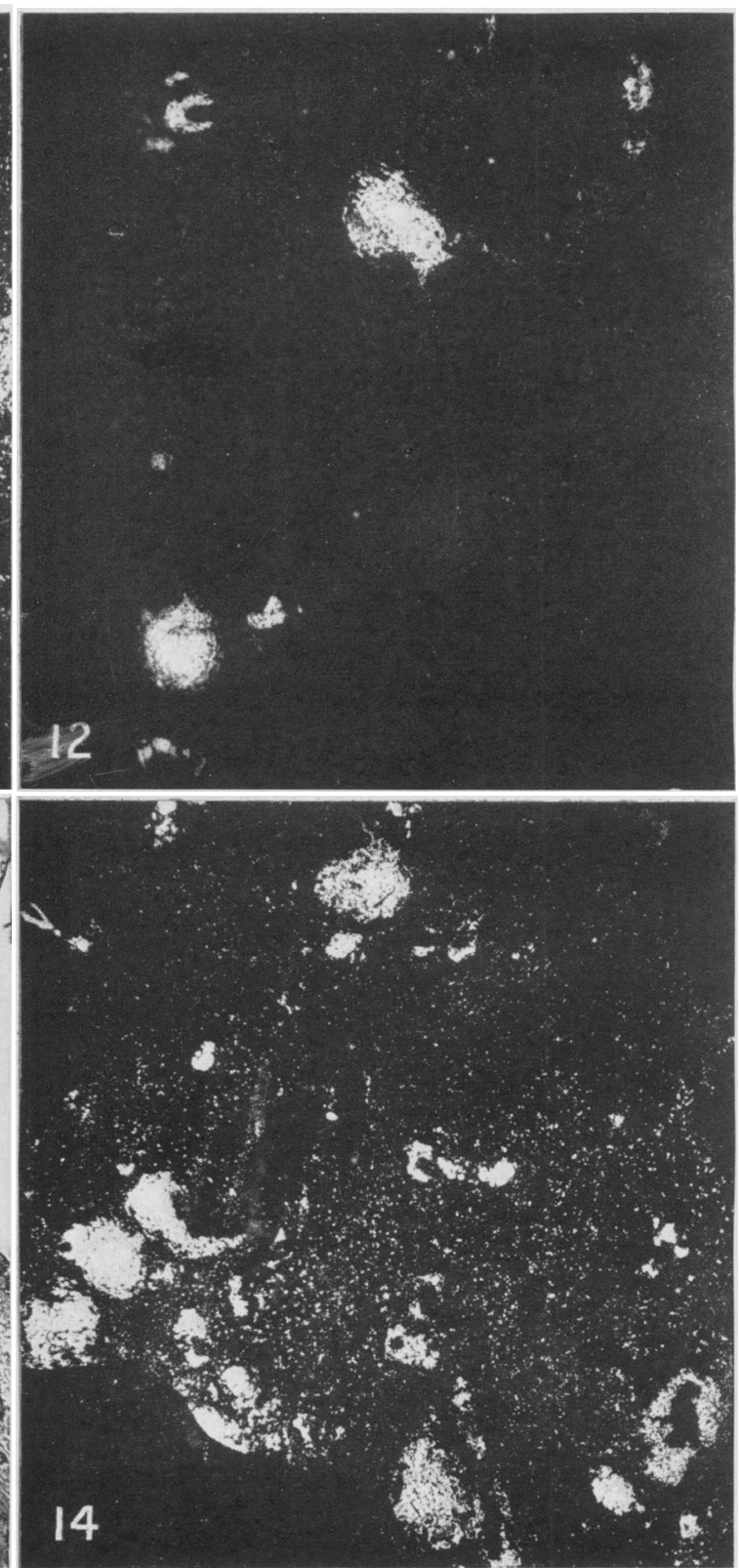

FIG. 12.- Same field as Fig. 8. Incinerated section showing silica ash. (x 25.)

FIG. 14.- Same field as Fig. 13. Incinerated section showing silica ash. 
TABLE 3

ASSESSMENT OF FIBROSIS IN SECTIONS OF LUNGS OF RATS RECEIVING QUARTZ AND QUARTZ-PLUS-ALUMINIUM*

\begin{tabular}{|c|c|c|c|c|c|c|c|c|c|c|}
\hline \multirow{2}{*}{$\begin{array}{c}\text { Days } \\
\text { from } \\
\text { begin- } \\
\text { ning of } \\
\text { experi- } \\
\text { ment }\end{array}$} & \multicolumn{5}{|c|}{ Quartz-dusted rats } & \multicolumn{5}{|c|}{ Quartz-plus-aluminium-dusted rats } \\
\hline & $\begin{array}{c}\text { No. (480 } \\
\text { series) }\end{array}$ & $\begin{array}{c}\text { Total } \\
\text { hours of } \\
\text { dusting }\end{array}$ & $\begin{array}{l}\text { No. of } \\
\text { nodules }\end{array}$ & $\begin{array}{c}\text { Maximum } \\
\text { size of } \\
\text { nodules } \\
(\mu)\end{array}$ & $\begin{array}{l}\% \text { of } \\
\text { area of } \\
\text { section } \\
\text { fibrosed }\end{array}$ & $\begin{array}{c}\text { No. (481 } \\
\text { series) }\end{array}$ & $\begin{array}{c}\text { Total } \\
\text { hours of } \\
\text { dusting }\end{array}$ & $\begin{array}{c}\text { No. of } \\
\text { nodules }\end{array}$ & $\begin{array}{c}\text { Maximum } \\
\text { size of } \\
\text { nodules } \\
(\mu)\end{array}$ & $\begin{array}{c}\% \text { of } \\
\text { area of } \\
\text { of section } \\
\text { fibrosed }\end{array}$ \\
\hline 28 & 1 & 125 & 0 & - & 3 & 1 & 125 & 0 & - & 1 \\
\hline 40 & - & - & - & - & - & 2 & 125 & 0 & - & 1 \\
\hline 56 & 2 & 130 & 0 & 一 & 5 & 二 & - & - & - & - \\
\hline 186 & 3 & 1067 & 0 & - & $10 \S$ & - & - & - & - & - \\
\hline 196 & 一 & - & - & - & - & 3 & 1210 & 5 & 126 & $2=$ \\
\hline 201 & - & - & - & - & - & $4 \div$ & 1267 & 6 & 126 & 2 \\
\hline 220 & 4 & 1514 & 11 & 237 & 6 & - & - & - & - & - \\
\hline 222 & $5 \ddagger$ & 1514 & 25 & 345 & 4 & - & - & - & - & - \\
\hline 290 & - & - & - & - & - & 5 & 2236 & 87 & 105 & 2 \\
\hline 306 & $6_{+}^{+}$ & 2350 & 49 & 713 & 5 & $6 \ddagger$ & 2350 & 62 & 280 & 3 \\
\hline 354 & - & - & - & - & - & 8 & 2407 & 116 & 303 & 3 \\
\hline 357 & - & - & - & - & - & 9 & 2407 & 27 & 172 & 1 \\
\hline 363 & 9 & 2424 & 140 & 1123 & 6 & - & - & 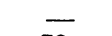 & - & - \\
\hline 365 & - & - & - & - & - & 11 & 2424 & 72 & 194 & 4 \\
\hline 371 & - & - & - & - & - & 12 & 2424 & $(90) \dagger$ & $(750) \dagger$ & $(3 i) \dagger$ \\
\hline 38 & - & - & 二 & - & - & 13 & 2614 & 24 & & 1 \\
\hline 3 & - & - & - & - & - & 14 & 2652 & 76 & 497 & 3 \\
\hline 391 & - & - & - & - & - & 15 & 2690 & 68 & 475 & 5 \\
\hline 39 & 13 & 2880 & 85 & 915 & 10 & $16_{+}^{+}$ & 2767 & 82 & 475 & 2 \\
\hline 408 & $14_{+}^{+}$ & 2937 & 110 & 972 & 13 & - & - & - & - & _- \\
\hline 42 & $15^{+}$ & 3060 & 102 & 850 & 17 & - & - & - & - & - \\
\hline 420 & 16 & 3060 & 57 & 650 & 14 & - & - & - & - & - \\
\hline 420 & 17 & 3060 & 79 & 750 & 19 & - & - & - & - & - \\
\hline
\end{tabular}

* The tabulated results represent the histological appearance of a single transverse section of the whole lung cut across the mid region at the level of the hilus. The "No. of nodules" represents the total number of foci of reticulinosis or fibrosis seen in the section; the "Maximum size of nodule" the largest focus of reticulinosis or of nodular fibrosis seen; and the " $\%$ of area of section fibrosed" the total area of fibrosis, and/or reticulinosis, including nodules and peribronchial fibrosis, expressed as a percentage of the area of the whole section.

1 The results in this animal are completely at variance with all the others in the quartz-plus-aluminium group. We believe that this animal was from the quartz group and got into the quartz-plus-aluminium group by mistake (see p. 34).

$\ddagger$ Sections reproduced in figures.

$\S$ Heavy peribronchial fibrosis.

aluminium according to the micro-analytical procedures outlined by King (1947). (Tables 1 and 2).

\section{Pathological Findings}

The results of the experiment are summarized in Table 3, in which the findings in quartz-dusted rats are compared with those in rats dusted with quartzplus-aluminium.

The figures in the table were obtained as follows. Coronal sections were cut through the lung from hilum to pleura and included some hilar glands. Silver-impregnated sections were examined microscopically for evidence of reticulin formation, and any circumscribed collection of reticulin fibrils in the lung parenchyma was designated as a " nodule". All such nodules in one whole section were counted and the largest one measured, the mean of the longest and shortest diameter (in the case of oval nodules) being regarded as a diameter. The whole section was then projected on to squared paper and traced in. From these drawings the total area of the section and the total area covered by reticu- linoses or fibrous tissue of any sort were calculated and the area of fibrosis expressed as a percentage. In practice this fibrosis included not only abnormal connective tissue in lung and hilar glands but also the normal peribronchial and perivascular connective tissue. From this it follows that the "area of section fibrosed" in a normal lung is not 0 per cent.

Since we have not previously obtained satisfactory experimental silicosis by dusting, and since the lesions which we have now obtained differ from those produced by the single intratracheal injection technique, it is desirable to describe our findings in some detail.

Rats Dusted with Quartz Alone.-In the first three rats, which survived 28,56 , and 186 days, there was no focal reticulinosis which could be regarded as a nodule. There was some thickening of an occasional alveolar wall and some doubtful increase of perivascular fibrous tissue, and in Rat 3 there was slight reticulinosis of the hilar glands. In Rats 4 and 5 (220 and 222 days' survival) there were a few focal 
collections of dust-laden phagocytes, each of which was traversed by a delicate network of fine reticulin fibrils (Fig. 3). These " nodules" were roughly rounded, usually associated with small vessels, and were never bigger than $345 \mu$, though most of them were much smaller than this. In both rats there were foci of collagenous fibrosis in the hilar glands.

In the rats which survived 300 days or more, the lesions were typical of nodular silicosis (Figs. 5, 7, and 9). They consisted now of collagen in the form of dense rounded nodules with a few fibroblast nuclei but no dust cells. These mature nodules became larger and more numerous in rats surviving for about 400 days (Fig. 7). It is interesting, however, to note that after 300 days nodules of varying ages were visible (Figs. 5 and 7). Those referred to above as mature nodules were not the only ones present : amongst them were quite numerous nodules of the early type seen at 200 days. We presume that the mature nodules resulted from dust inhaled early in the experiment and that as dusting continued further nodules developed from dust inhaled later. In all animals surviving 300 days or more there was gross collagenous fibrosis of the hilar glands.

We were not able to find any evidence of emphysema in these rats, either in the vicinity of the lesions or elsewhere.

Rats Dusted with Quartz-plus-Aluminium.-The first two rats (28 and 40 days' survival) showed no lesion attributable to dusting. In the two rats surviving for 196 and 201 days there were a few foci of dust cell reaction, but most of these were free from reticulin increase. There were, however, five and six foci respectively in which a few reticulin fibrils could be found, and these were counted as "nodules" (Fig. 4). They were, however, much less dense and only about half the size of the nodules in the corresponding group of quartzdusted rats.

In the remaining rats, which survived 290 to 397 days, the lesions were less numerous than in the quartz-dusted animals and they differed markedly in respect of both size-and density (Figs. 6, 8, and 10). None of them reached a diameter of $500 \mu$, although the nodules due to quartz alone reached almost double this diameter; and none of them became fully collagenous. An occasional nodule had some collagen fibres, but the vast majority consisted only of a loosely woven tangle of fine reticulin fibrils. (Rat 12 was a striking exception and showed the typical lesions of silicosis. We were able to show that this rat had no aurine-staining aluminium in its lungs ; its fellows showed well-marked aurine stain- ing of the inhaled dust.* We therefore presume that Rat 12 was accidentally transferred to the wrong group.)

The hilar glands in the rats surviving $\mathbf{3 0 0}$ days or more showed fully developed collagenous fibrosis, strikingly more severe than any of the lung lesions.

Comparison of Quartz and Quartz-plus-Aluminium. -No focal lesions were seen in either group before 196 days. After this time there were nodules of reticulinosis in both groups, but they were fewer in the quartz-plus-aluminium group (average of 56 per section compared with 73 per section in the pure quartz group). In the quartz and aluminium group the "nodules" remained as masses of tangled reticulin fibrils up to 400 days, whilst those in the pure quartz group became collagenous after 300 days. The most striking difference, however, was the size of the nodules. This is apparent when the maximum nodule size is compared (Figs. 9 and 10), but it is even more striking when the percentage areas of fibrosis are compared. The highest figure in the quartz-plus-aluminium group is 5 per cent., whilst in the pure quartz group this figure is achieved at 200 days ; in six rats the figure is 10 per cent. or more.

In both groups sections from each rat were incinerated, washed in acid, and examined for silica. In both groups it was found that all the dust visible in ordinary sections was siliceous, and that in any individual nodule the concentration of dust was as high in the quartz-plus-aluminium lung as in the pure quartz lung (Figs. 11 and 12).

\section{Discussion}

The most interesting problem raised by these experiments is whether we have prevented experimental silicosis in animals, or merely retarded it. Fig. 6 of the lung of a rat dusted with mixed quartz and aluminium for 306 days looks not quite as advanced in its pathological aspect as Fig. 3 of a rat dusted with quartz for 222 days ; and Fig. 8 of a 397 day quartz-plus-aluminium-dusted rat is not nearly as fibrosed as the lung of a 306-day quartz-dusted rat (Fig. 5). The net impression is that the presence of the 2 per cent. of aluminium has slowed up the pathogenic action of the quartz by something like 200 days. Whether the slight nodular reticulinosis' in the lungs of quartz-plus-aluminium rats at about 400 days would eventually have proceeded to fullblown collagenous silicosis if the animals had lived long enough can only be guessed; but further

* Spot-test analysis of a thick section, cut from the same block and ashed after extraction with light petroleum, revealed only a trace of aluminium-not much more than that found in quartz animals and much less than that in comparable samples from the quartz-plusaluminium lungs. 
experiments may show if it is possible permanently to inhibit the effect of quartz as long as the animals can be kept alive. Starting with young, freshly weaned animals, this is usually something of the order of two years with laboratory-bred rats of the strain used. A repeat experiment has been in progress for several months, and we hope to secure an answer to the question whether aluminium prophylaxis of experimental silicosis can lead to a genuine prevention or only to a retardation of the development of silicotic fibrosis. At present, it seems certain that, like Denny and others, we have greatly retarded silicosis development, since there was just as much dust, found by analysis as well as by microincineration, in the lungs of quartz-plus-aluminiumdusted animals as in those dusted with quartz (Table 4).

TABLE 4

ANALYSIS OF LUNGS OF EXPERIMENTAL ANIMALS

\begin{tabular}{|c|c|c|c|c|}
\hline \multirow{2}{*}{$\begin{array}{c}\text { No. } \\
\text { (480 } \\
\text { series) }\end{array}$} & \multirow{2}{*}{$\begin{array}{l}\text { Quartz-dusted rats } \\
\mathrm{SiO}_{2} \\
\text { (\% in dried lung) }\end{array}$} & \multirow{2}{*}{$\begin{array}{l}\text { No. } \\
(481 \\
\text { series })\end{array}$} & \multicolumn{2}{|c|}{$\begin{array}{l}\text { Quartz-plus- } \\
\text { aluminium- } \\
\text { dusted rats }\end{array}$} \\
\hline & & & $\underset{(\% \text { in dri }}{\mathrm{SiO}_{2}}$ & $\begin{array}{l}\mathrm{Al}_{2} \mathrm{O}_{3} \\
\mathrm{~d} \text { lung) }\end{array}$ \\
\hline $\begin{array}{r}1 \\
2 \\
4 \\
5 \\
6 \\
9 \\
13 \\
14 \\
15 \\
16\end{array}$ & $\begin{array}{l}1 \cdot 7 \\
1.6 \\
2.7 \\
1.4 \\
0.8 \\
1.6 \\
2.1 \\
2.0 \\
1.5 \\
2 \cdot 1\end{array}$ & $\begin{array}{r}1 \\
2 \\
4 \\
5 \\
6 \\
9 \\
13 \\
14 \\
15 \\
16\end{array}$ & $\begin{array}{l}1 \cdot 1 \\
1 \cdot 1 \\
1.8 \\
2.8 \\
1.1 \\
2.4 \\
2.6 \\
3.0 \\
3 \cdot 1 \\
2.6\end{array}$ & $\begin{array}{l}0.06 \\
0.06 \\
0.08 \\
0.10 \\
0.04 \\
0.08 \\
0.10 \\
0.12 \\
0.13 \\
0.08\end{array}$ \\
\hline
\end{tabular}

- All lung tissue not used for histology was dried at $105^{\circ} \mathrm{C}$ powdered, dried again to constant weight, re-ground, well mixed, and analysed for silica by the method of King (1939) and for aluminium by that of Alten and others (1933) as modified by King, 1947.

The bearing of this and similar investigations on the problem of human silicosis can only be discussed very briefly. Following on Denny and others' demonstration of prevention of silicosis with aluminium in animals, large-scale prophylactic and therapeutic trials were instituted in. many industries in Canada and the United States. Reports by Crombie and others (1944), Hannon (1944), Bamberger (1945), Johns and Petronella (1945), and Rauschenbach and others (1948), have been in some cases cautiously, in others unreservedly favourable. Berry (1948), on the other hand, has been unable to demonstrate any statistically valid improvement in the condition of silicotic miners treated with the hydroxide of aluminium which Gardner and others (1944) found to be effective in preventing silicosis in rabbits. Because of the very great medical and social importance of any possible treatment or preventive measure for silicosis the Medical Research Council has begun an investigation on the effect of aluminium treatment of silicosis in selected industries. Results of these experiments will be awaited with great interest. But they will take a long time ; and in the meantime it is useful to explore how fully aluminium can be relied upon to serve as an antidote to siliceous dust in animals. For the moment, the careful investigation and suppression of industrial dust seems to be the only way in which there can be any confident control of this most serious of industrial diseases.

\section{Summary}

1. Dusting experiments have been conducted in which rats were exposed for eighteen hours a day to an atmosphere containing about 30,000 particles of pure quartz per ml. on the one hand, and of quartz combined with 2 per cent. of powdered aluminium on the other.

2. Nodular reticulinosis was present in the lungs of quartz-dusted rats from about the two hundredth day, and fully developed collagenous silicosis from about the three hundredth day.

3. The quartz-plus-aluminium-dusted rats had almost no reticulinosis in their lungs at two hundred days, and only very slight reticulinosis at three hundred days. The longest lived rats in this group (about four hundred days) had reticulin nodules only a little more advanced than those in the quartz group at two hundred days.

4. There was just as much quartz in the lungs of the quartz-plus-aluminium animals as in those dusted with pure quartz.

5. A retardation of about two hundred days, or possibly a prevention, of the development of silicotic lesions in the lungs of animals has been secured by the inclusion of 2 per cent. of metallic aluminium powder in the quartz.

We are grateful to the Medical Research Council for a grant to defray the expenses of this investigation. Miss V. Pash, Mr. C. G. Johnston, and Mr. W. Weedon rendered valuable technical assistance, and Mr. E. V. Willmott prepared the photomicrographs.

\section{REFERENCES}

Alten, F., Weiland, H., and Loofmann, H. (1933). Angew. Chem 46., 668 .

Bamberger, P. J. (1945). Industr. Med., 14, 477.

Belt, T. H., and King, E. J. (1943). J. Path. Bact., 55, 69.

Belt, T. H., (1945). Spec. Rep. Ser. med Res. Coun. Lond., no. 250 , p. 29 
Berry, J. W. (1948) Amer. Rev. Tuberc., 57, 557.

Crombie, D. W., Blaisdell, J. L., and MacPherson, G. (1944). Denny, J. J., Robson, W. D., 318 and Irwin, D .A. (1937). Canad. med. Ass. J., 37, 1 ; (1939). 40,213.

Gardner, L. U., Dworski, M., and Delahant, A. B. (1944). J. indust. Hyg., 26, 211.

Gordon, H., and Sweets, H. H., Jr. (1936). Amer. J. Path., 12, 545 Green, H. L., and Watson, H. H. (1935). Spec. Rep. Ser. med. Res. Coun., no. 199, London.

Hannon, J. W. G.? 1944). Trans. Canad. Inst. Min. Metall., 47, 180.
Johns, D. R., and Petronella, S. J. (1945). Monthly Bull. Indiana State Bd. of Health, 43, 203.

and Hilton, R. (1932). Lancet, 1, 1190

King, E. J. (1939). Biochem. J., 33, 944.

(1947). Occup. Med., 4, 26

Rogers, N., and Gilchrist, M. (1945). J. Path. Bact., $57,281$.

- - Harrison, C. V., and Nagelschmidt, G. (1948). Ibid., 60, 435.

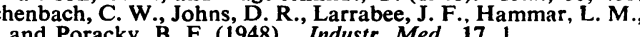
and Poracky, B. F. (1948). Industr. Med., 17, 1 .

Wright, B. M. (1948). British Provisional Patent, No. 3326\%. 